\title{
Anatomical Features of the Sieve Elements in the Vascular Bundles of Rosaceae Fruit Trees
}

\author{
Naosuke $\mathrm{Nii}$ \\ College of Agriculture, Meijo University, Tempaku, Nagoya 468
}

\begin{abstract}
Summary
The anatomy of the sieve elements in the vascular bundle in a variety of Rosaceae fruit trees-peach (Prunis persica (L.) Batsch.), plum (Prunus salicina Lindl.), Japanese apricot (Prunus mume Sieb. et Zucc.), apple (Malus domestica L. Borkh.), Japanese pear (Pyrus pyrifolia Nakai), and loquat (Eriobotrya japonica Lindl.) was observed by both optical and transmission electron microscopy. As a comparison, sieve elements of satsuma mandarin (Citrus unshiu Marc.), Japanese persimmon (Diospyros kaki L. f.), and grape (Vitis vinifera L.) were examined. A distinguishing feature of the thickening portion of the sieve elements in the vascular bundles of the midrib. petiole, fruit stalk, and pericarp in Rosaceae fruit species appeared to be structural ingrowth of the cell wall, but only as a trace in the roots. From the anatomical observations, the ingrowth thickening in the sieve elements, which is referred to as nacreous wall formation, was completely different from the apparatus of the transfer cells. This sieve-element structure is a characteristic feature of Rosaceae fruit trees, in which sorbitol is the main photosynthetic product. In contrast, the sieve elements of fruit stalks of the other species, whose principal translocatory carbohydrate is sucrose, do not appear similar.
\end{abstract}

\section{Introduction}

Since Abbe and Crafts (1939) have reported the presence of thick, "secondary" walls in the sieve elements of Pinaceae, many researchers observed similar thickened walls (nacreous walls) in the sieve elements of terrestrial vascular plants (Esau and Cheadle, 1958; Srivastava, 1969; Neuberger and Evert, 1974; Evert and Eichhorn, 1976; Kuo, 1983; Behnke, 1989). Detailed ultrastructural studies have been made of these walls. The recent proposal by Chafe and Dooham (1972) that microfibrils lie flat in the plane of the cell wall is consistent with a generally accepted view. Although the nacreous features of the sieve elements have been reported in fruit trees, such as Prunus and Pyrus (Esau and Cheadle, 1958), detailed information on the vascular development in fruit trees remains scarce. During a study of the vascular bundles in many fruit trees, I found how the structure of the sieve element wall develops in many Rosaceae fruit trees. General morphology of these

Received for publication 22 June 1992. walls was similar to that of the nacreous walls of the sieve elements of other plants. In contrast, no such structure was found in the sieve elements of citrus, grape, and Japanese persimmon.

It is well-established that sorbitol is the major photosynthetic product in mature leaves of many woody Rosaceae plants. Furthermore, sorbitol plays a major role in the carbohydrate economy of these plants, even though the concentration of sorbitol changes with the development of the leaf (Webb and Burley, 1962; Bieleski and Redgwell, 1985). In addition, the mature leaf exports carbohydrates, mainly in the form of sorbitol, into the sink organs of these plants (Webb and Burley, 1962; William et al., 1967; Bieleski, 1969, 1982; Williams and Raese, 1974). The principal pathway of the carbohydrates is phloem tissue, particularly the sieve elements. The mechanisms of carbohydrate translocation from the leaf involve both symplastic and apoplastic pathways. Many reports have addressed the plasmodesmata and the cell wall protuberance of transfer cells. The role of the nacreous-like cell structure of the sieve element of Rosaceae fruit trees is of interest with regard to 
the mechanism of translocation of carbohydrate products.

To obtain information about the translocatory cell structure of Rosaceae fruit trees, the anatomy of the sieve elements in the vascular bundles was studied.

\section{Materials and Methods}

The vascular bundles of the Rosaceae fruit stalks were observed by optical and transmission electron microscopy during the various stages of fruit development of the following; peach (Prunus persica (L.) Batsch cv. Hakuto), plum (Prunus salici. na Lindl. cv. Sordum), Japanese apricot (Prumus mume Sieb. et. Zucc. cv. Shirokaga), apple (Malus domestica L. Borkh. cv. Fuji), Japanese pear (Pyrus pyrifolia Nakai cv. Kosui), and loquat (Eriobotrya japonica Lindl. cv. Tanaka). For comparison, the fruit stalks of satsuma mandarin (Citrus unshiu Marc. cv. Okitsuwase), Japanese persimmon (Diospyros kaki L.f. cv. Fuyu), and grape (Vitis vinifera L. cv. Muscat of Alexandria) were examined. In addition, the development of sieve elements in the vascular bundles of the midrib, petiole, pericarp, and root of Rosaceae was observed.

The tissues were cut with a razor blade and fixed in $3 \%$ glutaraldehyde $(0.1 \mathrm{M}$ phosphate buffer, $\mathrm{pH} 7.2$ ) at $4^{\circ} \mathrm{C}$ until they were sectioned. The fixed specimens were dehydrated through a graded ethanol-acetone series, embedded in Spurr resin (Spurr, 1969), thin-sectioned $(1.5 \mu \mathrm{m})$, and stained with methylene blue for optical microscopy. For electron microscopy, the tissues were fixed in $3 \%$ glutaraldehyde and $2 \%$ osmic acid. After specimens were dehydrated and embedded in Spurr resin, the ultrathin sections were stained with uranyl acetate and then with lead citrate (Reynolds, 1963). They were examined by a JEOL model 100CX electron microscope.

\section{Results and Discussion}

The distinctive ingrowth in the sieve elements of the fruit stalks was observed in all the Rosaceae plants investigated (Figs. 1 and 2 ). In contrast, no such structure was found in the sieve elements of the other 3 species (Fig. 2D). Specifically, the Rosaceae plants demonstrated the following degrees of ingrowth-like thickening in their sieve elements: (1) that in the loquat was markedly developed; (2) that in the peach, plum, and Japanese apricot was intermediate; (3) that in the apple and Japanese pear was either not noticeable or barely visible. The ingrowth-like development of the sieve elements in the vascular bundles occurs in the midrib (Fig. 1C) and pericarp (Fig. 2B) in all the Rosaceae plants; whereas, it was not as evident in roots (Fig. 1D). The ingrowth-like structure in the sieve elements extended longitudinally along the cell wall (Fig. 1B). A typical ultrastructural features of these elements in the midrib of a peach leaf is the nacreous wall formation of the sieve elements (Fig. 3). These protrusions apparently gave rise to the vesicular structures which accumulated outside the plasmalemma, as reported by Evert and Eichhorn (1976). During nacreous wall formation, the vesicles and other organelles in the cytoplasm eventually collapsed and degenerated (Fig. 3C and D).

The appearance of this ingrowth structure was completely different from that of the transfer cell reported previously (Pate and Briarty, 1968; Gunning and Pate, 1969; Pate and Gunning, 1972). The distinct morphological feature of that ingrowth structure developed smoothly and became thick enough to be clearly visible by means of optical microscopy. On the other hand, the cell wall protuberance (ingrowth) of the transfer cell develops in a highly irregular structure. The transfer cell has its nucleus, usually central; its cytoplasm has vacuoles, chloroplasts with grana and starch grains, and numerous mitochondria with well-developed cristae. Also observed are dictyosomes and a rough endoplasmic reticulum, as well as numerous polyribosomes and plasmodesmata. It is possible that the capacity for loading and translocating nutrients from the source organs is promoted by an increase in the transfer cell's inner surface area (Pate and Briarty, 1968; Gunning and Pate, 1969; Pate and Gunning, 1972).

The structural ingrowth in the sieve elements of woody Rosaceae plants occurs at the expense of the cytoplasm; consequently, the cell organelles in the cytoplasm almost disappear. Evert and Eichhorn (1976) and Kuo (1983) reported that the sieve element protoplast retains a good deal of the cell organelles during most of the period when the nacreous wall material is being deposited. Neuberger and Evert (1974) reported that the mature, plasmalemma-lined sieve tube cell contains a degenerated nucleus, mitochondria, and intact plas- 


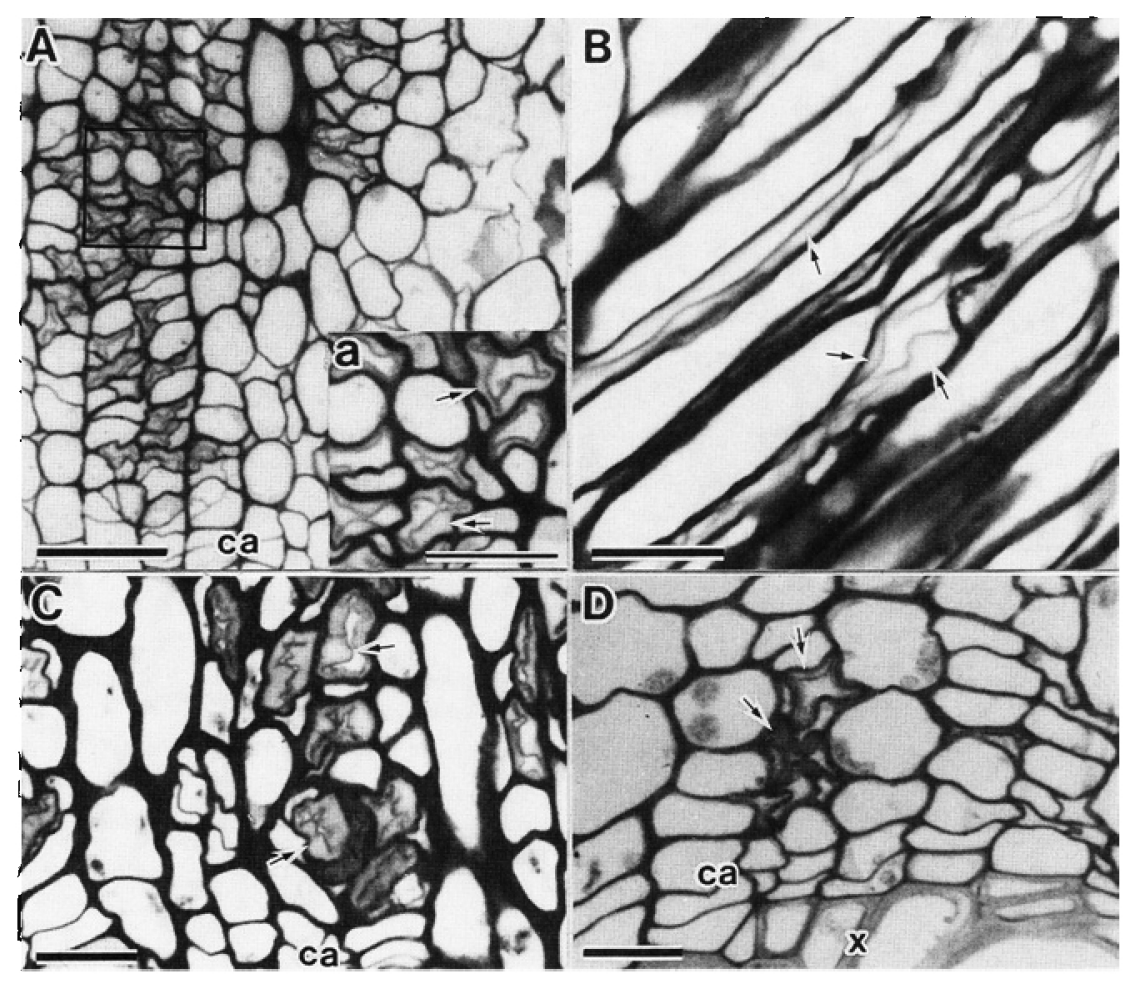

Fig. 1. Optical micrographs of sections of fruit stalks (A; transversal section, B; longitudinal section), midrib (C), and root (D) of peach. a is a detail of the boxed area in A. Arrows indicate the ingrowth structure of the sieve element. ca: cambium layer, $\mathrm{x}$ : xylem. Scale bar: $20 \mu \mathrm{m}$ (A, C, D), $10 \mu \mathrm{m}(\mathrm{B}, \mathrm{a})$.

tids, but that dictyosomes, ribosomes, and vesicular membranes are lacking. Furthermore, open pores that occur in sieve plates and branching plasmodesmata are present in enlarged sieve areas (Kuo, 1983). However, in the present observation the plasmodesmata was not detected even by transmission electron microscopy. In mature peach leaves the sieve elements of the midrib contained no organelles in the cytoplasm. The behavior and development of the nacreous layer are also quite variable and are dependent upon the type of organs, the age of the sieve elements, and the growing conditions (Kuo, 1983). In some sieve elements the nacreous layer may or may not be reduced in thickness as the cell ages (Esau and Cheadle, 1958; Evert and Eichhorn, 1976). In the Rosaceae phloem, the volume of cell wall increased apparently by reduction in cytoplasmic volume. An investigation of the above-mentioned Rosaceae plants reveals that the ingrowth-like development of the cell wall in the sieve elements is a very widespread component of the vascular bundle in the various tissues. Such a development, not only in the fruit stalk but also in other tissues, could be related to the translocation mechanism.

In many woody Rosaceae plants the translocatory product from the leaf mesophyll is sorbitol (Webb and Burley, 1962; Williams et al., 1967; Williams and Raese, 1974; Bieleski, 1969, 1982). Sorbitol is readily accumulated or loaded by the phloem-loading mechanism (Webb and Burley, 1962; Bieleski, 1969; Bieleski and Redgewell, 1985). Furthermore, the absolute concentration of sorbitol is particularly high in the phloem sap; values of approximately 15 to $25 \%$ have been recorded (Zimmermann and Ziegler, 1975). Sorbitol has also been found in xylem sap, in concentrations ranging from $0.02 \%$ to as high as $0.8 \%$ 


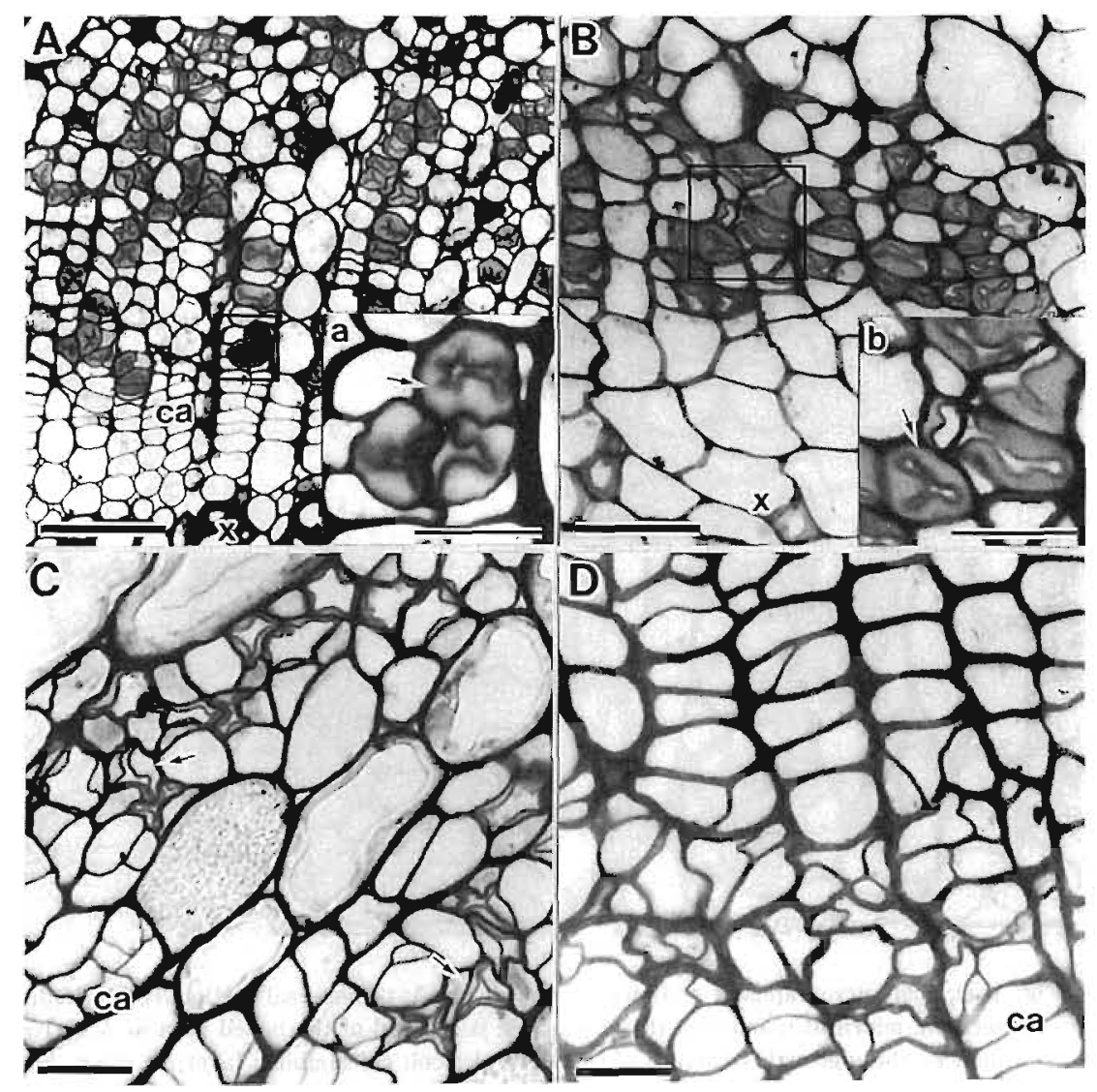

Fig. 2. Optical micrographs of sections of fruit stalk (A) and pericarp (B) of loquat, and fruit stalk of Japanese pear (C) and satsuma mandarin (D). a and b are details of the boxed areas in $\mathrm{A}$ and $\mathrm{B}$, respectively. Arrows indicate the ingrowth structure of the sieve element. ca: cambium layer, $\mathrm{x}$ : xylem. Scale bar: $40 \mu \mathrm{m}$ (A), $20 \mu \mathrm{m}$ (B, C, D), $10 \mu \mathrm{m}$ (a, b).

at certain times of the year (Williams and Raese, 1974; Hansen and Grauslund, 1978; Raese et al., 1978). The movement of sorbitol in the xylem is likely to be an important process, particularly in the early spring (Webb and Burley, 1962). However, sorbitol has always been the major carbohydrate found in the phloem of woody Rosaceae plants.

In the majority of these plants in which the nacreous walls of sieve elements occur, sorbitol is not the main carbohydrate to be translocated. Accord ing to Kuo (1983), whether there is any physiological significance in the reduction in the size of the lumen of sieve elements with nacreous wall in re. lation to the translocation rate in seagrasses re- mains to be determined. Recently, Behnke (1989) also reported that the function of the nacreous walls was not yet known. However, the ingrowth structure in the sieve element in the vascular bundles of the various tissues of the Rosaceae plants may be connected specifically with sorbitol translocation or loading, given that it was absent in the other species, e.g., citrus, Japanese persimmon, and grape, whose translocatable carbohydrate is main. ly sucrose.

\section{Literature Cited}

Abbe, L. B. and A. S. Craft. 1939. Phloem of white pine and other coniferous species. Bot. Gaz. 100 : $695-722$ 


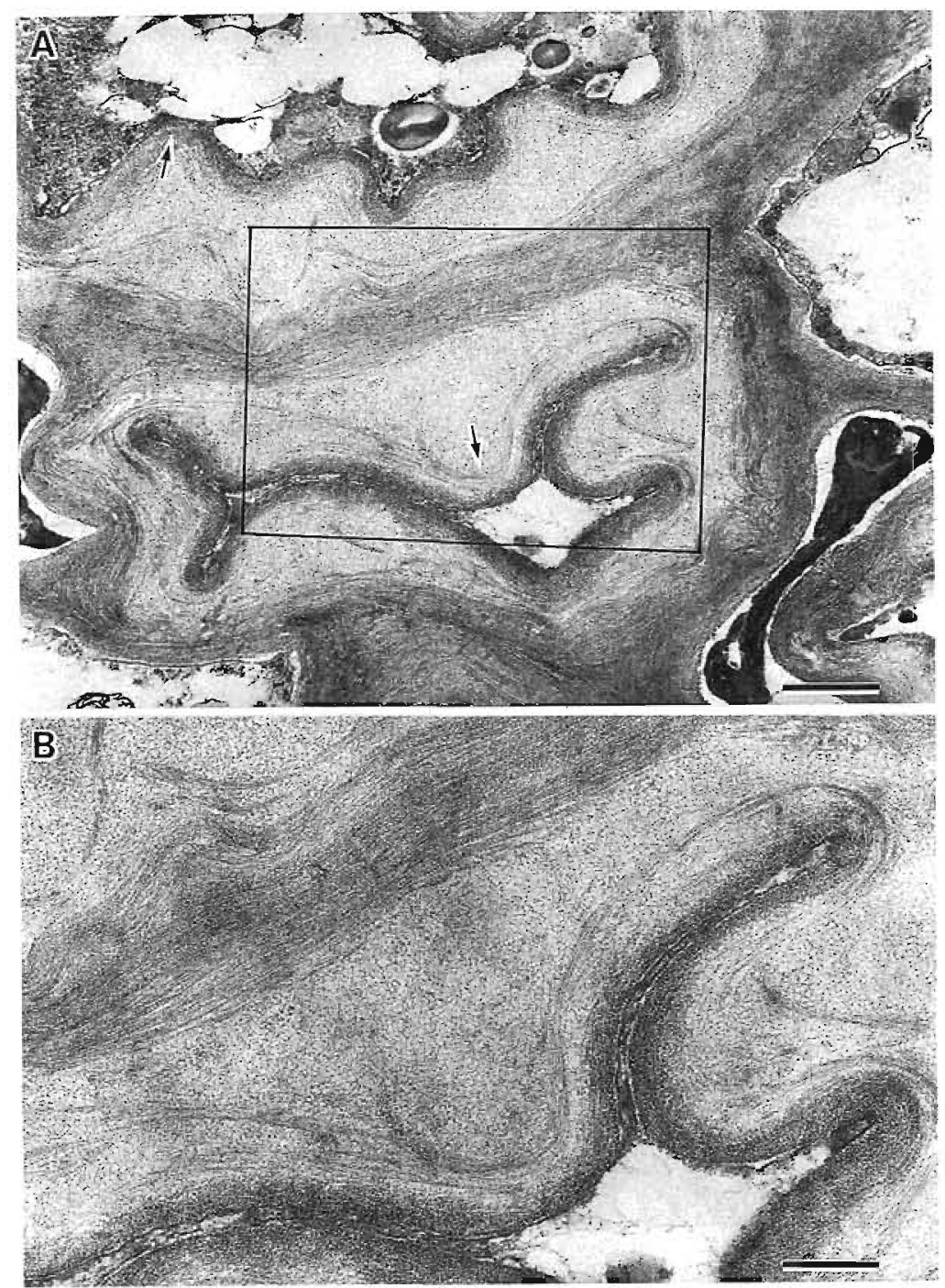

Fig. 3a. Details are given in Fig. 3b.

Behnke, H. D. 1989. Structure of the phloem. p. 79-111. In: D. J. Baker and J. A. Milburn (eds.). Transport of photoassimilate. Longman.

Bieleski, R. L. 1969. Accumulation and translocation of sorbitol in apple phloem. Aust. J. Biol. Sci. 22 : 611-620.

Bieleski, R. L. 1982. Sugar alcohols. p. 158-192. In: F. A. Loewus and W. Tanner (eds.). Plant carbohydrates I. Intercellular carbohydrates. Encycl. Plant Physiol. New Series. Vol. 13A. SpringerVerlag, Berlin.
Bieleski, R. L. and R. J. Redgwell. 1985. Sorbitol versus sucrose as photosynthesis and translocation products in developing apricot leaves. Aust. J. Plant Physiol. $12: 657-668$.

Chafe, S. C. and M. E. Dooham. 1972. Observations on the thickened sieve cell wall in Pinus strobus $\mathrm{L}$. Protoplasma $75: 67-78$.

Esau, K. and V. I. Cheadle. 1958. Wall thickening in sieve elements. Proc. Nat. Acad. Sci. U.S.A. 44 : 546-553.

Evert, R. F. and S. E. Eichhorn. 1976. Sieve-element 

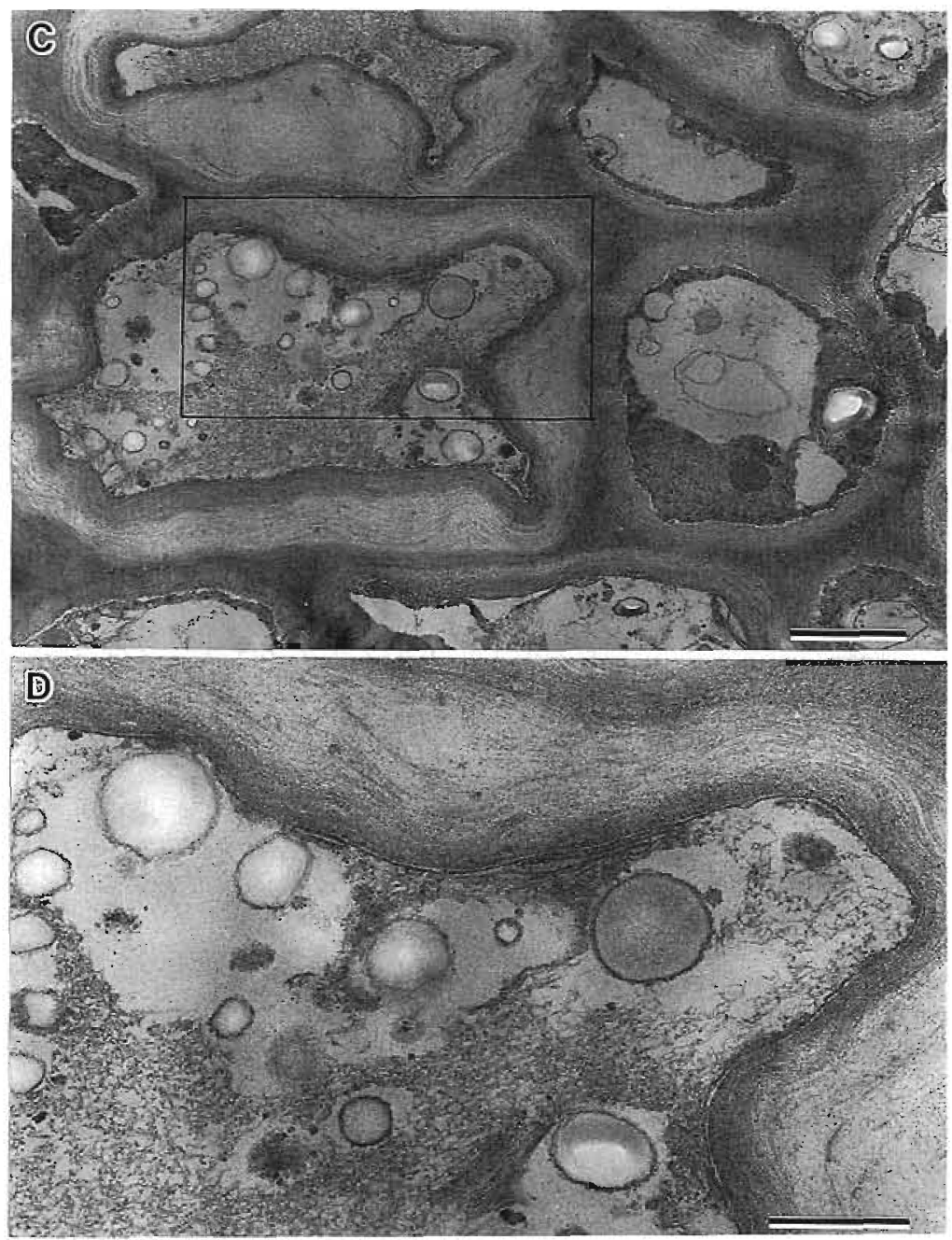

Fig. 3b Transmission electron micrographs of transversal sections of the midrib in peach leaves. $B$ and $D$ are details of the boxed area in $A$ and $C$, respectively. Arrows indicate the ingrowth structure of the sieve element. Scale bar: $2 \mu \mathrm{m}$ (C), $1 \mu \mathrm{m}(\mathrm{A}, \mathrm{D}), 0.5 \mu \mathrm{m}(\mathrm{B})$.

ultrastructure in Platycerium bifurcatum and some other polypodiaceous fern: the nacreous wall thickening and maturation of the protoplast. Amer. J. Bot. $63: 30-48$.

Gunning, B. E. S. and J. S. Pate. 1969. "Transfer cells" plant cells with wall ingrowths, specialized in relation to short distance transport of solutes their occurrence, structure, and development. Protoplasma 68 : 107-133.

Hansen, P. and J. Grauslund. 1978. Levels of sorbitol in bleeding sap and in xylem sap in relation to leaf mass and assimilate demand in apple trees. Physiol. Plant. 42 : 129-133.

Kuo, J. 1983. The nacreous walls of sieve elements in seagrasses. Amer. J. Bot. $70: 159-164$.

Neuberger, D. S. and R. F. Evert. 1974. Structure and development of the sieve-element protoplast in the hypocotyl of Pinus resiuosa. Amer. J. Bot. 61 : 360-374.

Pate, J. S. and L. G. Briarty. 1968. Specialized "transfer cells" in minor veins of leaves and their possible significance in phloem translocation. J. Cell 
Biol. $37: 7-12$.

Pate, J. S. and B. E. S. Gunning. 1972. Transfer cells. Ann. Rev. Plant Physiol. 23 : 173-196.

Raese, J. T., M. W. Williams and H. D. Billingsley. 1978. Cold hardiness, sorbitol, and sugar levels of apple shoots as influenced by controlled temperature and season. J. Amer. Soc. Hort. Sci. $103: 796-801$.

Reynolds, E. S. 1963. The use of lead citrate at high $\mathrm{pH}$ as an electron opaque stain in elelctron microscopy. J. Cell Biol. 17 : 206-212.

Spurr, A. R. 1969. A low viscosity epoxy resin embedding medium for electron microscopy. J. Ultrastructural Res. $26: 31-43$.

Srivastava, L. M. 1969. On the ultrastructure of cambium and its vascular derivatives. II. The secondary walls of the sieve elements of Pinus strobus.
Amer. J. Bot. 56 : 354-361.

Webb, K. L. and J. W. A. Burley. 1962. Sorbitol translocation in apple. Science $137: 766$.

Williams, M. W., G. C. Martin and E. A. Stahly. 1967. The movement and fate of sorbitol- $\mathrm{C}^{14}$ in the apple tree and fruit. Proc. Amer. Soc. Hort. Sci. 90 : 20-24.

Williams, M. W. and J. T. Raese. 1974. Sorbitol in tracheal sap of apple as related to temperature. Physiol. Plant. 30:49-52.

Zimmermann, M. H. and H. Ziegler. 1975. List of sugars and sugar alcohols in sieve tube exudates. p. 480-503. In: M. H. Zimmermann and J. Milburn (eds.). Transport in plants I. Phloem transport. Encyclopedia of Plant Physiology. New Series. Vol. I. Springer-Verlag, Berlin.

\title{
バラ科の果樹類における師管の細胞壁の内部生長
}

\section{新居直祐}

\section{名城大学農学部 468 名古屋市天白区}

\begin{abstract}
摘 要
数種のバラ科の果樹類 (モモ, スモモ, ウメ,リン ゴ, ニホンナシ, ビワ）について，師管の細胞構造を 光学顕微鏡ならびに透過型電子顕微鏡を使って観察し た。また，カンキツ，カキ，ブドウを対照樹として用 いた．その結果，バラ科の果樹類の中肋，葉柄，果柄， 果肉中の維管束の師管細胞において, 細胞壁が肥厚し, 内部生長した特徵的な構造がみられた。いっぽう，根

においてはこのような構造の発達は少なかった。細 胞構造の観察から師管が内部生長した細胞壁はnacreous wall とみなされ，転送細胞とは異なったもの であった、ソルビトールが主要な転流糖であるバラ科 の果樹類において，師管の細胞壁の内部生長が観察さ れたが，スクロースの形態で主として転流する対照樹 ではみられなかった。
\end{abstract}

